\title{
Manure Nutrient Excretion by Lactating Cows Fed Exogenous Phytase and Cellulase
}

\author{
K. F. Knowlton, ${ }^{\star 1}$ M. S. Taylor, ${ }^{\star}$ S. R. Hill, ${ }^{\star}$ C. Cobb, $†$ and K. F. Wilson $\dagger$ \\ *Virginia Polytechnic Institute and State University, Blacksburg 24061 \\ †Animal Feed Technologies, LLC, Greeley, CO 80632
}

\begin{abstract}
The effect of an exogenous phytase and cellulasecontaining enzyme formulation on nutrient digestibility and excretion was evaluated in 24 Holstein cows. Cows were fed corn silage- and alfalfa silage-based diets with or without a cellulase-phytase blend for $31 \mathrm{~d}$ in a continuous random design. Treatment groups were balanced for parity, days in milk, and mature-equivalent projected milk yield. Diets contained $37 \%$ forage, $18.3 \%$ crude protein, $35.4 \%$ neutral detergent fiber, $18 \%$ acid detergent fiber, and $0.42 \% \mathrm{P}$ (no supplemental $\mathrm{P}$ ). Cows were fed once daily in Calan doors and milked 2 times daily. Body weight and milk yield were recorded at each milking. Milk samples were collected on d 28 to 31 at 8 consecutive milkings. On d 28 to 31 , fecal grab samples were collected every $8 \mathrm{~h}$, with sampling times advanced by $2 \mathrm{~h}$ each day. Feces samples were pooled by cow. Feed and feces samples were analyzed for acid detergent lignin (used as an internal marker) and for $\mathrm{N}, \mathrm{P}$, neutral detergent fiber, and acid detergent fiber. Days in milk were similar between treatments, and body weight and milk yield were unaffected by treatment. Cows fed the enzyme formulation had reduced fecal dry matter, neutral detergent fiber, and acid detergent fiber excretion and reduced fecal excretion of $\mathrm{N}$ and $\mathrm{P}$. Apparent digestibility of dry matter, acid detergent fiber, neutral detergent fiber, and $\mathrm{N}$ tended to increase with the enzyme formulation. Addition of an exogenous phytase and cellulase enzyme formulation to diets for lactating cows reduced fecal nutrient excretion.
\end{abstract} Key words: manure excretion, phytase, cellulase, lactating cow

\section{INTRODUCTION}

Development of nutritional strategies to reduce $\mathrm{N}$ and $\mathrm{P}$ excretion by livestock is an important aspect of

Received December 21, 2006.

Accepted May 13, 2007.

${ }^{1}$ Corresponding author: Knowlton@vt.edu long-term efforts to reduce nutrient loading to water resources. The Natural Resources Conservation Service (NRCS) approved a Feed Management Conservation practice standard (Code 592; NRCS, 2003) with the purpose of "supply[ing] the quantity of available nutrients required by livestock and poultry for maintenance, production, performance, and reproduction; while reducing the quantity of nutrients, especially nitrogen and phosphorus, excreted in manure by minimizing the overfeeding of these and other nutrients." Practice standards published by the NRCS provide guidance for applying conservation technology. Inclusion of feed management on this list highlights its importance as a best management practice.

Among the specific feed management practices listed by the NRCS (2003) is "using selected enzymes or other products to enhance feed digestibility or feed use efficiency." The impact of feed additives on the availability of $\mathrm{P}$ in feedstuffs is worth exploring, because assumptions of availability of feed $\mathrm{P}$ in ruminants are based on relatively few studies. Improved $P$ availability from feed would allow the tissue-level needs of the animal to be met with reduced $\mathrm{P}$ intake, thus reducing the $\mathrm{P}$ content of livestock manure. The use of phytase additives in diets for monogastric animals is one approach to manipulate $\mathrm{P}$ availability and excretion.

Little work has been done to test the impact of phytase treatment on the availability of dietary $\mathrm{P}$ in ruminants in vivo. The endogenous phytase activity provided by ruminal bacteria makes $\mathrm{P}$ in grains and forages more available to ruminants than to nonruminants (Clark et al., 1986; Morse et al., 1992). Bacterial phytase activity is cell associated rather than external, as is typical of the fungus Aspergillus (Yanke et al., 1999). Because $P$ intake and excretion are tightly linked, even small improvements in the availability of feed $\mathrm{P}$ for ruminants should improve whole-farm $\mathrm{P}$ balance and reduce the potential for $\mathrm{P}$ runoff from farms (Knowlton et al., 2004). Recent work suggests the opportunity to reduce excretion or improve digestibility of $\mathrm{P}$ in goats, dry cows, and lactating cows (Bravo et al., 2002; Kincaid et al., 2005; Knowlton et al., 2005) with 
the inclusion of exogenous phytase, but effects vary with forage content and grain source.

Supplementing ruminal enzyme activity to enhance carbohydrate digestion is another approach to enhance the efficiency of nutrient utilization. Cellulose and hemicellulose are digested by the cellulase and xylanase produced by ruminal bacteria and protozoa. These fibrolytic enzymes have been isolated from fungal cultures and may be applied to forage, grain, or TMR. The response to feeding exogenous fibrolytic enzymes is highly variable. Although no effect has been observed in several studies with lactating cows (Higgenbotham et al., 1996; Vicini et al., 2003), increased digestibility (Beauchemin et al., 1999; Rode et al., 1999; Yang et al., 1999; Kung et al., 2000; Yang et al., 2000), feed intake (Lewis et al., 1999), and milk yield (Lewis et al., 1999; Rode et al., 1999; Yang et al., 2000) have been observed. Increased DM digestibility would imply decreased fecal DM output from cows fed exogenous enzymes, but few studies have reported manure production data. The objective of the study was to evaluate the effect of an enzyme formulation combining cellulase enzymes and phytase on feed intake, milk yield, and digestibility of $\mathrm{N}$, P, fiber, and DM in lactating Holstein cows.

\section{MATERIALS AND METHODS}

\section{Cows, Diets, and Sampling}

Twenty-four Holstein cows were fed diets with or without the addition of a phytase-cellulase enzyme formulation (Cattle-Ase-P; Animal Feed Technologies, Greeley, CO) for $31 \mathrm{~d}$ in a continuous random design. The diets were based on corn silage and alfalfa silage, and contained $37 \%$ forage, $18.3 \% \mathrm{CP}, 35.4 \% \mathrm{NDF}, 18 \%$ $\mathrm{ADF}$, and $0.42 \% \mathrm{P}$ (no supplemental $\mathrm{P}$ ). The granular enzyme formulation was mixed with a corn grain carrier, and the enzyme-corn grain mixture or control (an equal quantity of corn grain containing no enzyme formulation) was added to the diet at feeding (297 $\mathrm{g}$ of enzyme/tonne of DM; dosage based on the recommendations of the manufacturer). The enzyme formulation was mixed with its corn grain carrier 1 to $3 \mathrm{wk}$ prior to use. Diets were identical except for the inclusion of the enzyme or control formulation. The ingredient and nutrient composition of diets is presented in Table 1.

Treatment groups were balanced for parity (mean = 2.6 for the control diet and 2.4 for the treatment diet), DIM (95 \pm 45 and $95 \pm 36$, respectively), and matureequivalent projected milk yield $(25,869 \pm 1,744$ and $25,939 \pm 2,825$, respectively). Research animals were cared for according to the standard practices of the Virginia Tech Dairy Cattle Center and were approved by the Animal Care Committee.
Table 1. Ingredient and nutrient composition of diets fed to Holstein cows

\begin{tabular}{lc}
\hline Item & Dietary DM \\
\hline & $-(\%)-$ \\
Corn silage & 22.2 \\
Legume-grass silage & 14.8 \\
High-moisture shelled corn & 27.4 \\
Pressed brewers grains & 12.2 \\
Whole cottonseed & 10.2 \\
Soybean meal, 44\% protein & 10.5 \\
Vitamin-mineral mix ${ }^{1}$ & 2.7 \\
& $(\% \pm \mathrm{SE})^{2}$ \\
NDF & $35.4 \pm 0.62$ \\
ADF & $18.0 \pm 0.16$ \\
Acid detergent lignin & $3.29 \pm 0.09$ \\
NE ${ }_{\mathrm{L}}{ }^{3}$ Mcal/kg & 1.67 \\
$\mathrm{CP}$ & $18.3 \pm 0.15$ \\
$\mathrm{P}$ & $0.42 \pm 0.0$ \\
Phytate $\mathrm{P}^{4}$ & $0.17 \pm 0.0$ \\
$\mathrm{Ca}$ & $0.90 \pm 0.0$ \\
\hline
\end{tabular}

${ }^{1}$ Vitamin-mineral premix contained $24.78 \% \mathrm{Ca} ; 0.01 \% \mathrm{P} ; 1.42 \%$ $\mathrm{Mg} ; 0.08 \% \mathrm{~K} ; 8.3 \% \mathrm{Na} ; 4.22 \% \mathrm{Cl} ; 0.03 \% \mathrm{~S} ; 11.1 \mathrm{mg} / \mathrm{kg}$ of Co; $278 \mathrm{mg} /$ $\mathrm{kg}$ of Cu; $2,742 \mathrm{mg} / \mathrm{kg}$ of Fe; $24.3 \mathrm{mg} / \mathrm{kg}$ of I; $1,043 \mathrm{mg} / \mathrm{kg}$ of $\mathrm{Mn} ; 11.3$ $\mathrm{mg} / \mathrm{kg}$ of Se; $1,113 \mathrm{mg} / \mathrm{kg}$ of $\mathrm{Zn} ; 183,810 \mathrm{IU} / \mathrm{kg}$ of vitamin A; 61,280 IU/kg of vitamin D; $767 \mathrm{IU} / \mathrm{kg}$ of vitamin E.

${ }^{2}$ Weekly ingredient samples ( $\mathrm{n}=5 \mathrm{wk}$ ).

${ }^{3}$ Calculated (NRC, 2001).

${ }^{4}$ Phytate $\mathrm{P}$ content of the diet calculated from literature values (Clark et al., 1986; Eeckhout and Paepe, 1994; van Doorn et al., 2004; Godoy et al., 2005).

The enzyme formulation was a commercial preparation from fungal extracts, with 15,000 units of cellulase activity/g and 5,000 units of phytase activity/g of additive (cellulase $=4,455 \mathrm{IU} / \mathrm{kg}$ of TMR DM; phytase $=$ $1,485 \mathrm{IU} / \mathrm{kg}$ of TMR DM). One unit of cellulase activity is defined as the cellulase activity that produces a relative fluidity change of 1.0 in $100 \mathrm{~min}$ in a $0.2 \%$ (wt/ vol) sodium carboxymethyl cellulose (CMC type 7HP, Hercules, Inc., Wilmington, DE) solution under assay conditions ( $\mathrm{pH} 4.5$ and $40^{\circ} \mathrm{C}$ ), as measured with a size 100 Calibrated Cannon-Fiske type viscometer. One unit of phytase activity is defined as the phytase activity that releases $1.0 \mu \mathrm{mol}$ of phosphate/min under assay conditions ( $\mathrm{pH} 5.5$ and $37^{\circ} \mathrm{C}$ ).

Cows were individually fed in Calan doors (American Calan, Northwood, NH) once daily at $1200 \mathrm{~h}$ and had constant access to their diet except during milking. Feed was offered 5 to $10 \%$ in excess of the previous day's intake (wet basis). Cows were milked twice daily at 0100 and $1300 \mathrm{~h}$. Body weight and milk yield were recorded for all cows at each milking. Milk samples were collected at 8 consecutive milkings on d 28 to 31 . On d 28 to 31, fecal grab samples were collected every $8 \mathrm{~h}$, with sampling times advanced by $2 \mathrm{~h}$ each day to account for diurnal variation. Dried and ground feces samples were pooled by cow across sampling time. Feed ingredients (grains and forages) were sampled weekly. 
Table 2. Feed intake, milk yield, and BW change in Holstein cows fed a phytase-cellulase or control formulation

\begin{tabular}{lcccc}
\hline Item & Control & Enzyme & SEM & $P<$ \\
\hline DMI, kg/d & 25.9 & 25.1 & 0.70 & 0.46 \\
Milk yield, kg/d & 37.8 & 38.8 & 1.52 & 0.63 \\
Milk yield, kg/kg of DMI & 1.48 & 1.64 & 0.08 & 0.19 \\
Milk fat, kg/d & 1.47 & 1.58 & 0.08 & 0.32 \\
3.5\% FCM, $1 \mathrm{~kg} / \mathrm{d}$ & 40.2 & 42.5 & 1.76 & 0.36 \\
Milk protein, kg/d & 1.12 & 1.15 & 0.05 & 0.69 \\
Milk lactose, kg/d & 1.83 & 1.89 & 0.07 & 0.56 \\
SNF, kg/d & 3.32 & 3.42 & 0.14 & 0.59 \\
MUN, mg/dL & 23.5 & 22.3 & 0.48 & 0.08 \\
BW, kg & 595.8 & 601.3 & 14.2 & 0.78 \\
BW change, kg/31 d & -4.13 & -14.2 & 4.67 & 0.12 \\
\hline
\end{tabular}

${ }^{1} \mathrm{FCM}: \mathrm{kg} / \mathrm{d}=(0.4324 \times$ milk yield, $\mathrm{kg} / \mathrm{d})+(16.216 \times$ milk fat yield, $\mathrm{kg} / \mathrm{d})$.

\section{Laboratory Analysis}

Samples of feed ingredients and feces were dried to a constant weight at $60^{\circ} \mathrm{C}$ in a forced-air drying oven (Wisconsin Oven, Memmert, Schwabach, Germany). Dried samples were ground through a 2 -mm screen in a Wiley mill (Arthur H. Thomas, Philadelphia, PA). Feed and feces samples were analyzed in duplicate for $\mathrm{N}, \mathrm{P}$ (AOAC, 1984), NDF, ADF, and acid detergent lignin sequentially with $\alpha$-amylase (Van Soest et al., 1991). Feces excretion was estimated by using lignin as an internal marker (fecal output = lignin intake/ fecal lignin concentration), and nutrient digestibility was calculated. Milk samples were analyzed for fat, protein, lactose, MUN, and SNF (DHIA, Blacksburg, VA).

\section{Statistical Analysis}

The effects of diet on milk yield and milk components, BW, and feed intake were analyzed by PROC MIXED, with day as a repeated measure and cow (treatment) as the random statement. Pretrial milk yield (3-d average) was used as a covariate for analysis of milk yield and composition data (SAS Institute, 1999). The effect of treatment on nutrient digestibility and excretion were analyzed with PROC GLM (no repeated measures). Differences were declared significant at $P<0.05$ and trends at $P<0.15$. Results are reported as least squares means.

\section{RESULTS AND DISCUSSION}

Dry matter intake, BW, and milk yield were unaffected by treatment (Table 2). Content and yield of milk protein, fat, lactose, and SNF were similar between groups, but MUN content tended to be lower in cows fed the enzyme. Cows fed the enzyme formulation tended to lose more weight across the 31-d experimental period. No explanation is apparent, but feed efficiency, milk
Table 3. Dry matter and fiber intake and digestibility in Holstein cows fed a phytase-cellulase or control formulation

\begin{tabular}{lcccc}
\hline Item & Control & Enzyme & SEM & $P<$ \\
\hline Feces DM, kg/d & 9.55 & 7.66 & 0.38 & 0.01 \\
DM digestibility, ${ }^{1} \%$ & 64.0 & 68.9 & 2.32 & 0.13 \\
ADF intake, kg/d & 4.58 & 4.42 & 0.13 & 0.19 \\
Feces ADF, kg/d & 2.98 & 2.40 & 0.11 & 0.01 \\
ADF digestibility, \% & 35.9 & 45.0 & 3.75 & 0.09 \\
NDF intake, kg/d & 8.78 & 8.49 & 0.24 & 0.19 \\
Feces NDF, kg/d & 5.20 & 4.20 & 0.20 & 0.01 \\
NDF digestibility & 41.8 & 49.8 & 3.34 & 0.09 \\
\hline
\end{tabular}

${ }^{1} \mathrm{DM}$ digestibility calculated using acid-detergent lignin (ADL) as an internal marker. The ADL content of feces averaged $10.4 \%$.

yield per kilogram of DMI, was numerically greater for cows fed the enzyme formulation.

Cows fed the enzyme formulation had reduced feces DM excretion (Table 3). Apparent digestibility of DM, $\mathrm{NDF}$, and ADF tended to increase with the enzyme formulation (Table 3). When fibrolytic enzymes were applied to forage, grain, or TMR immediately prior to feeding lactating cows, increased digestibility (Beauchemin et al., 1999; Rode et al., 1999; Yang et al., 2000), feed intake (Lewis et al., 1999), and milk yield (Lewis et al., 1999; Rode et al., 1999; Yang et al., 2000) have been observed. On the other hand, some studies have reported no effect on feed intake (Rode et al., 1999; Schingoethe et al., 1999; Kung et al., 2000; Yang et al., 2000) or milk yield (Schingoethe et al., 1999; Vicini et al., 2003). The effects of directly fed fibrolytic enzymes in lactating cow diets are inconsistent, primarily because of differences in the source and activity of the fibrolytic enzymes. This inconsistency of results may also be due to differences in the energy status of the cows, diet composition, and method of application (Yang et al., 2000).

The mechanisms by which addition of exogenous enzymes may improve fiber digestion are complex and incompletely understood. They include stimulation of rumen microbial populations, increased bacterial attachment, and synergistic effects with enzymes of the ruminal microorganisms (Morgavi et al., 2000; Beauchemin et al., 2003). The magnitude of the increased fiber digestion observed in the current study is high compared with many other published reports. Our practice of mixing the enzyme formulation with its corn grain carrier 1 to $3 \mathrm{wk}$ in advance of use may have increased the efficacy by allowing binding to increase stability in the rumen (Beauchemin et al., 1999). In addition, fibrolytic enzymes are more likely to be of benefit when fiber digestibility is limited. The fiber in the diets in the current study was supplied by corn silage, cottonseed, and legume-grass silage. The latter was mature and of low quality (14.5\% protein, $36.8 \%$ $\mathrm{ADF}, 54.3 \% \mathrm{NDF}$ ). 
Table 4. Nitrogen and phosphorus intake and digestibility in Holstein cows fed a phytase-cellulase or control formulation

\begin{tabular}{lcccc}
\hline Item & Control & Enzyme & SEM & $P<$ \\
\hline Nitrogen intake, g/d & 740.2 & 703.4 & 37.5 & 0.50 \\
Fecal N excretion, g/d & 252.3 & 203.2 & 10.3 & 0.01 \\
Apparent N digestibility, \% & 66.5 & 70.8 & 2.19 & 0.15 \\
Phosphorus intake, g/d & 108.9 & 105.3 & 2.92 & 0.19 \\
Fecal P, g/d & 66.9 & 55.2 & 2.65 & 0.01 \\
Apparent total-tract P digestibility, \% & 39.6 & 46.1 & 4.01 & 0.29 \\
\hline
\end{tabular}

Finally, the diets in this study contained only $37 \%$ forage and $18 \% \mathrm{ADF}$. Ruminal $\mathrm{pH}$ was not measured, but the relatively low fiber content may have resulted in ruminal $\mathrm{pH}$ closer to the $\mathrm{pH}$ optima for the enzymes. The various enzyme fractions within the formulations used have relatively broad ranges. Cellulase activity in this formulation is optimal between $\mathrm{pH} 5.3$ and 7.1, and activity of the phytase is optimal between 4.0 and 4.5 .

Cows fed the enzyme formulation had reduced fecal excretion of $\mathrm{N}$ and $\mathrm{P}$ (Table 4). Intake of both $\mathrm{N}$ and $\mathrm{P}$ was similar across diets. Digestibility of $\mathrm{P}$ was unaffected, and digestibility of $\mathrm{N}$ tended to increase with the enzyme formulation. Reduced fecal excretion of $\mathrm{N}$ combined with a lower MUN concentration implies improved efficiency of utilization of absorbed $\mathrm{N}$ for maintenance, growth, or milk protein synthesis. The reduction in fecal $\mathrm{N}$ excretion may be explained by an overall increase in digestion of feed in the rumen.

Reduced fecal excretion of $\mathrm{P}$ is consistent with recent reports. Knowlton et al. (2005) observed that addition of a blend of phytase and cellulase (same formulation as in the current study) to the diets of lactating cows tended to increase apparent $\mathrm{P}$ digestibility (50.1 vs. 40.5\%). Kincaid et al. (2005) reported that hydrolysis of phytate $\mathrm{P}$ was increased by exogenous phytase, and total $\mathrm{P}$ digestibility tended to be increased. They concluded that although endogenous phytase activity occurs in the rumen, physical properties of the diet and ruminal passage rates may prevent total hydrolysis of phytate in the rumen of lactating cows. Bravo et al. (2003) reported that addition of fungal phytase increased $\mathrm{P}$ digestibility of formaldehyde-treated soybean meal and formaldehyde-treated sunflower meal, but had no effect on formaldehyde-treated rapeseed meal. In the current study, phytate P (Table 1; estimated from literature values) was relatively low, comprising $\sim 40 \%$ of total $\mathrm{P}$.

The effects of exogenous phytase may vary with the basal diet. In lactating goats and dry cows, Bravo et al. (2002) found that fungal phytase supplementation in a high-concentrate diet increased $\mathrm{P}$ release from rapeseed meal and soybean meal but had no effect when supplemented in a high-forage diet. The reduced effectiveness of exogenous phytase in high-forage diets may be due to a longer rumen retention time, thus extending the reaction time for ruminal endogenous phytase to hydrolyze phytic acid (Bravo et al., 2002). In addition, the predominant phytase-producing bacteria are starch-fermenting organisms (i.e., Selenomonas ruminantium; Yanke et al., 1999), which are at a competitive advantage in high-grain diets. The diets in the current study were relatively low in forage (Table 1) but high in NDF because of the inclusion of fibrous by-product feeds. More data are needed on the interaction of fungal phytase with the enzyme dose, grain source, and dietary forage content.

\section{CONCLUSIONS}

An exogenous phytase plus cellulase formulation reduced the fecal nutrient excretion of lactating cows and tended to increase the fiber and DM digestibility. Thus, use of exogenous enzyme formulations may provide an opportunity to reduce nutrient losses from dairy farms.

\section{REFERENCES}

AOAC. 1984. Official Methods of Analysis. 14th ed. AOAC, Arlington VA.

Beauchemin, K. A., D. Colombatto, D. P. Morgavi, and W. Z. Yang. 2003. Use of exogenous fibrolytic enzymes to improve feed utilization by ruminants. J. Anim Sci. 81(E. Suppl.):E37-E47.

Beauchemin, K. A., W. Z. Yang, and L. M. Rode. 1999. Effects of grain source and enzyme additive on site and extent of nutrient digestion in dairy cows. J. Dairy Sci. 82:378-390.

Bravo, D., F. Meschy, C. Bogaert, and D. Sauvant. 2002. Effects of fungal phytase addition, formaldehyde treatment and dietary concentrate on ruminal phosphorus availability. Anim. Feed Sci. Technol. 99:73-95.

Bravo, D., F. Meschy, C. Bogaert, and D. Sauvant. 2003. Phosphorus availability of oilseed meals determined by the apparent faecal digestibility technique. Anim. Feed Sci. Technol. 108:43-60.

Clark, W. D. J., J. E. Wohlt, R. L. Gilbreath, and P. K. Zajac. 1986. Phytate phosphorus intake and disappearance in the gastrointestinal tract of high producing dairy cows. J. Dairy Sci. 69:31513155 .

Eeckhout, W., and M. Paepe. 1994. Total phosphorus, phytate-phosphorus and phytase activity in plant feedstuffs. Anim. Feed Sci. Technol. 47:19-29.

Godoy, S., C. Chicco, F. Meschy, and F. Requena. 2005. Phytic phosphorus and phytase activity of animal feed ingredients. Interciencia 30:24-28.

Higginbotham, G. E., E. J. dePeters, S. L. Berry, and A. Ahmadi. 1996. Effect of adding a cell wall degrading enzyme to a total mixed ration for lactating dairy cows. Prof. Anim. Sci. 12:81-85. 
Kincaid, R. L., D. K. Garikipati, T. D. Nennich, and J. H. Harrison. 2005. Effect of grain source and exogenous phytase on phosphorus digestibility in dairy cows. J. Dairy Sci. 88:2893-2902.

Knowlton, K. F., C. M. Parsons, C. W. Cobb, and K. F. Wilson. 2005. Exogenous phytase plus cellulase and phosphorus excretion in lactating dairy cows. Prof. Anim. Sci. 21:212-216.

Knowlton, K. F., J. S. Radcliffe, D. A. Emmerson, and C. L. Novak. 2004. Animal management to reduce phosphorus losses to the environment. J. Anim. Sci. 82(E. Suppl.):E173-E195.

Kung, L., Jr., R. J. Treacher, G. A. Nauman, A. M. Smagala, K. M. Endres, and M. A. Cohen. 2000. The effect of treating forages with fibrolytic enzymes on its nutritive value and lactation performance of dairy cows. J. Dairy Sci. 83:115-122.

Lewis, G. E., W. K. Sanchez, C. W. Hunt, M. A. Guy, G. T. Pritchard, B. I. Swanson, and R. J. Treacher. 1999. Effect of direct-fed fibrolytic enzymes on the lactational performance of dairy cows. J. Dairy Sci. 82:611-617.

Morgavi, D. P., K. A. Beauchemin, V. L. Nsereko, L. M. Rode, A. D. Iwaasa, W. Z. Yang, T. A. McAllister, and Y. Wang. 2000. Synergy between ruminal fibrolytic enzymes and enzymes from Trichoderma longibrachiatum. J. Dairy Sci. 83:1310-1321.

Morse, D., H. H. Head, and C. J. Wilcox. 1992. Disappearance of phosphorus in phytate from concentrates in vitro from rations fed to lactating dairy cows. J. Dairy Sci. 75:1979-1986.

NRC. 2001. Nutrient Requirements of Dairy Cattle. 7th rev. ed. Natl. Acad. Sci., Washington, DC.

NRCS (Natural Resources Conservation Service). 2003. National Conservation Practice Standards-NHCP. http://www.nrcs.usda gov/technical/Standards/nhcp.html Accessed Dec. 15, 2006.

Rode, L. M., W. Z. Yang, and K. A. Beauchemin. 1999. Fibrolytic enzyme supplements for dairy cows in early lactation. J. Dairy Sci. 82:2121-2126.
SAS Institute. 1999. SAS User's Guide, Version 8.0. SAS Inst. Inc., Cary, NC.

Schingoethe, D. J., G. A. Stegeman, and R. J. Treacher. 1999. Response of lactating dairy cows to a cellulase and xylanase enzyme mixture applied to forages at the time of feeding. J. Dairy Sci. 82:996-1003.

van Doorn, D. A., H. Everts, H. Wouterse, and A. C. Beynen. 2004. The apparent digestibility of phytate phosphorus and the influence of supplemental phytase in horses. J. Anim. Sci. 82:1756-1763.

Van Soest, P. J., J. B. Robertson, and B. A. Lewis. 1991. Methods for dietary fiber, neutral detergent fiber, and nonstarch polysaccharides in relation to animal nutrition. J. Dairy Sci. 74:35833597.

Vicini, J. L., H. G. Bateman, M. K. Bhat, J. H. Clark, R. A. Erdman, R. H. Phipps, M. E. Van Amburgh, G. F. Hartnell, R. L. Hintz, and D. L. Hard. 2003. Effect of feeding supplemental fibrolytic enzymes or soluble sugars with malic acid on milk production. J. Dairy Sci. 86:576-585.

Yanke, L. J., H. D. Bae, L. B. Selinger, and K. J. Chen. 1998. Phytase activity of anaerobic ruminal bacteria. Microbiology 144:15651573.

Yanke, L. J., L. B. Selinger, and K. J. Cheng. 1999. Phytase activity of Selenomonas ruminantium: A preliminary characterization. Lett. Appl. Microbiol. 29:20-25.

Yang, W. Z., K. A. Beauchemin, and L. M. Rode. 1999. Effects of an enzyme feed additive on extent of digestion and milk production in lactating dairy cows. J. Dairy Sci. 82:391-403.

Yang, W. S., K. A. Beauchemin, and L. M. Rode. 2000. A comparison of methods of adding fibrolytic enzymes to lactating cow diets. J. Dairy Sci. 83:2512-2520. 